\title{
Data Mining Menggunakan Algoritma K-Nearest Neighbor Dalam Menentukan Kredit Macet Barang Elektronik
}

\author{
Silvilestari \\ Program Studi Manajemen Informatika, AMIK Kosgoro, Solok, Indonesia \\ Email: rendanghjfatimah@gmail.com \\ Email Penulis Korespondensi: rendanghjfatimah@gmail.com
}

\begin{abstract}
Abstrak-Bisnis merupakan kegiatan yang rutin dilakukan oleh banyak masyarakat, salah satu bisnis yang menjajikan adalah bisnis yang menyediakan kebutuhan barang elektronik untuk memeuhi kebutuhan kehidupan sehari-hari, peminat yang tinggi menyebabkan pebisnis harus lebih berhati-hati dan selektif dalam melihat pola customers yang ingin melakukan transaksi demi mengindari resiko bisnis dengan tepat. Para pebisnis melakukan sistem kredit untuk meningkatkan penjualan dalam kurun waktu lama, tetapi kendala yang sering terjadi adalah banyak pelanggan yang menggunakan jasa kredit sering melakukan keterlambatan dalam pembayaran hingga membuat keuangan perusahaan tidak stabil sehingga perlu prediksi seseorang untuk menentukan customer yang berpotensi melakukan kredit macet barang elektronik menggunakan sebuah sistem yang membantu pemilik usaha untuk mempermudah mengolah data dan prediksi pola kredit macet barang elektronik yang sudah terbentuk dari data sebelumnya mengunakan pendekatan algoritma KNN, sehingga hasilnya memperihatkan kedekatan nilai terhadap data customers lama baik yang membayar dengan layak dan yang melakukan pembayaran dengan macet dan dapat diperoleh proses pengolaha lebih mempercepat pengolahan data dengan hasil tepat dalam proses penyelesaian masalah.
\end{abstract}

Kata Kunci: Kredit Macet; Data Mining; Algoritma KNN

Abstract-Business is an activity that is routinely carried out by many people, one of the promising businesses is a business that provides the needs of electronic goods to meet the needs of daily life, high demand causes business people to be more careful and selective in seeing the pattern of customers who want perform transactions in order to avoid business risks appropriately. Business people use a credit system to increase sales for a long time, but the obstacle that often occurs is that many customers who use credit services often delay payments to make the company's finances unstable so someone needs to predict someone who has the potential to do bad credit for electronic goods. using a system that helps business owners to make it easier to process data and predict patterns of bad credit for electronic goods that have been formed from previous data using the KNN algorithm approach, so that the results show the closeness of the value to the data of old customers, both those who pay properly and those who make payments in default and it can be obtained that the processing process accelerates data processing with precise results in the problem solving process.

Keywords: Bad Credit; Data Mining; KNN Algorithm

\section{PENDAHULUAN}

Bisnis usaha merupakan kegiatan yang selalu dilakukan oleh seluruh masyarakat, bisnis usaha dengan banyak jenis dan beranekaragam membuat banyak pengusaha memikirkan bagaimana cara untuk meningkatkan usaha dengan beberapa strategi yang diperlukan, baik dari melihat peluang, kesempatan dan resiko dari proses pengelolahan bisnis usaha yang dijalankan, upaya untuk terus mengembangkan dan membuat bisnis usaha yang dijalankan dapat berkembang dengan cepat dan tepat. Bangkitnya sebuah bisnis usaha jika terjadi transaksi yang terus bergulir tanpa putus dan terus meningkat pada produk yang menjadi bisnis dari sebuah usaha, hal tersebut dapat dilakukan dengan cara melakukan menarik minat customers dengan melakukan promo dan layanan terbaik seperti memberikan kesempatan untuk melakukan kredit untuk mendapatkan produk yang diinginkan dan dengan adanya sistem kredit akan menimbulkan beberapa resiko nantinya[1].

Dalam sistem kredit akan menjadi hal yang sangat merugikan sebuah perusahaan jika tidak mampu mengolah dan mengenali customer yang akan mengalami kesulitan dalam peroses pelunasan barang yang telah disepakati sebelumnya maka akan terjadi kemacetan dan penyendatan terhadap lalu lintas biaya produksi sebuah perusahaan sehingga perlu dilakukan prediksi untuk melihat pola konsumen terhadap kredit macet barang elektronikyang akan berdampak buruk kedepannya dengan melihat data lama sebagai rekaman terhadap jejak kecenderungan customer terhadap proses pembayaran. Dalam mengenali pola dilakukan proses penengenalan dengan menerapkan sebuah sistem komputer untuk mempermudah dalam mengelola, mengakses dan mengedit data dengan cepat dan akurat. Keseluruhan data kerdit yang menjadi data penting yang berhubungan dengan proses dan pemberian izin terhadap kredit sebuah produk, selajutnya sistem yang diterapkan menggunakan pendekatan kecerdasan teknologi dengan menggunakan ilmu data mining[2], [3].

Data mining sendiri merupakan cabang ilmu penalaran yang diprogram untuk membantu mempermudah para manusia dalam mendapatkan informasi untuk semua bidang yang menggunakan dan mengolah data untuk menggali dari data yang sangat banyak. Data yang dimaksud adalah data yang sudah bertumpuk dan memerlukan proses dalam mengenali, klasifikasi, pengelompokan dan proses prediksi hingga mendapatkan ilmu maupun informasi yang benar-benar dibutuhkan. Data mining memiliki banyak teknik dengan proses seleksi data salah satunya algoritma KNN[4], [5]. 
Algoritma KNN singkatan dari algoritma K-Nearest Neighbor yang melihat jarak ecluiden antara kasus lama dan dibandingkan dengan kasus baru dalam upaya pengenalan data supervised atau data yang sudah ada dan sudah terekam untuk membantu pengambilan keputusan terhadap kasus terbaru, algoritma ini sangat banyak diterapkan pada penelitian lainnya dikarenakan algoritma ini memiliki langkah-langkah dan proses penalaran logika yang sangat sederhana dengan menghasilkan data dan keputusan yang tepat, beberapa penelitian terdahulu dalam penggunaan algoritma ini sudah menjelaskan kemampuan algoritma ini dalam membantu menyelesaikan permasalahan yang berkaitan dengan kasus lama dan kasus baru[6]-[9].

Pada penelitian terdahulu algoritma K-nearest neighbor digunakan untuk mengklasifikasi terhadap data senitimen beberapa masyarakat yang tampak dari tweets, dalam hal ini proses klasifikasi dilakukan untuk memilah dari banyaknya pengguna twiter terhadap responabel seseorang terhadap keadaan masa pandemic atau covid-19 untuk melihat dampak yang dirasakan masyarakat tersebut dalam bentuk persentase dan data yang cukup untuk memperlihatkan hasil keputusan dalam kasus yang dihadapi peneliti. Penelitian lainnya mengguakan algoritma K-nearest neighbor untuk melakukan deteksi penyakit kanker pada proses ini peneliti melakukan pegumpulan data lama dengan hasil kelas pernyataan terhadap hasil diagnosis untuk melakukan deteksi dini secara komputerisasi untuk membantu menyelesaikan tahapan awal deteksi penakit kanker yang dialami oleh beberapa pasien, hal ini dilakukan untuk mengetahui tindak lanjut terhadap pasien dengan keputusan kelas terdeteksi atau tidaknya, hasil yang ditemukan memiliki akurasi yang cukup tepat dengan memanfaatkan data terdahulu secara diagnosis pakar[10][5].

Penelitian lainnya algoritma ini bandingkan dengan algoritma klasifikasi lain seperti K-nearest neighbor dengan algoritma K-means untuk melakukan klasifikasi terhadap daerah prioritas pelayanan akta kelahiran dengan menghasilkan algoritma K-nearest neighbor lebih memberikan kemudahan dalam proses yang sangat sederhana dan mempercepat proses pengambilan keputusan. Pada penelitian ini algoritma K-nearest neighbor membantu melakukan seleksi terhadap customer baru yang ingin melakukan transaksi dalam bentuk perjanjian kredit agar tidak terjadi kerugian terhadap bisnis usaha yang memberikan kredit dan terus membantu proses optimalisasi biaya operasional[11][12].

\section{METODOLOGI PENELITIAN}

Setiap penelitian tentunya memiliki tahapan dalam proses penyelesaian permasalahan dalam rangka mempermudah seseorang dalam mengetahui apa-apa saja yang akan dilakukan dalam sebuah penelitian agar penelitian tersebut menghasilkan data yang benar dan tepat, pada tahapan proses megumpulkan data, teoristis, metode penyelesaian masalah yang ditentukan hal tersebut disebut dengan metodologi penelitian. Pada penelitian ini menggunakan jenis metodologi kuantitatif dimana jenis metode ini membantu para peneliti dalam meyelesaikan permasalahan secara logika yang menghasilkan data bersifat statistik, pada tahapannya memperlihatkan proses matematika membantu menemukan penyelesaian masalah dan menyajikan informasi dalam bentuk angka[13].

\subsection{Pengumpulan Data}

Proses pengumpula data khusunya dalam hal melihat kredit macet barang elektronikpara customer dilakukan dengan cara melihat dokumen atau data lama yang sebelumnya telah tersimpa dan tercatat, dan melakukan pencatatan terhadap data yang baru masuk dengan memberikan lembaran kuesioner sebagai data penunjang untuk mengetahui identitas customer yang dibutuhkan sebagai bahan pertimbagan pengambilan keputusan. Pengambilan data lainnya dilakukan dengan cara melakukan teknik studi pustaka, pada tahapan tersebut akan menambahkan nilai penelitian lebih terpecaya dan membantu peneliti dalam menyelesaian permasalahan dari berbagai sumber lainnya[14].

\subsection{Kredit Macet}

Kredit macet barang elektronik merupakan sebutan bagi orang-orang yang melakukan penyendatan atau kesulitan dalam membayarkan hutang berupa uang yang harus dibayarkan dalam kurun waktu tertentu setelah melakukan pengambilan barang, biasanya kredit diberikan untuk meningkatkan minat beli masarakat terhadap produk yang ditawarkan oleh para pemegang bisnis usaha, adanya kredit macet barang elektronikmembuat biaya operasional menjadi tidak berjalan dengan baik dan dapat menimbulkan permasalahan lainnya terhadap perusahaan.

\subsection{Algoritma K-Nearest Neighbor}

Adapun tahapan dalam penyelesaian permasalahan menggunakan metode K-nearest neighbor adalah sebagai berikut ini[15]-[17]:

$\mathrm{Dij}=\sqrt{x i i-x i i)+x 2 i-x 2 i+\cdots(x i i-x 2 i)}$

Keterangan :

Dij=Jarak dari data ke i ke pusat cluster $\mathrm{i}$

$\mathrm{Xxi}=$ Data dari data ke- $\mathrm{i}$ keattribute data data ke $-\mathrm{K}$ 


\section{JURNAL MEDIA INFORMATIKA BUDIDARMA}

Volume 5, Nomor 3, Juli 2021, Page 1063-1067

ISSN 2614-5278 (media cetak), ISSN 2548-8368 (media online)

Available Online at https://ejurnal.stmik-budidarma.ac.id/index.php/mib DOI 10.30865/mib.v5i3.3100

$\mathrm{Xkj}=$ Data dari data ke- $\mathrm{j}$ keattribute data data $\mathrm{ke}-\mathrm{K}$

Adapun tahapan penyelesaian permasalaha menggunaka algoritma ini adalah sebagai berikut ini:

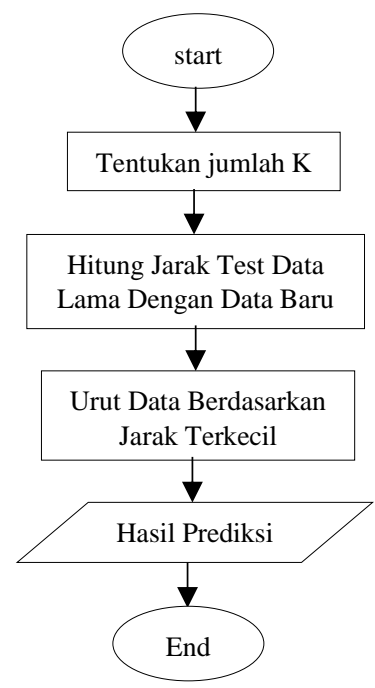

Gambar 1. Tahapan K-Nearest Neighbor

\section{HASIL DAN PEMBAHASAN}

Hasil dari penelitian ini akan menunjukan informasi terhadap kemungkinan pelaku kredit macet barang elektronik selanjutnya, sehingga perlu dilakukan klasifikasi terhadap data baru yang mengajukan kredit untuk menghadapi kemungkinan terburuk dalam memberikan izin terhadap customer untuk dapat melakukan kredit terhadap barang yang dibutuhkan customer, pada penelitian ini diketahui data training dan data test:

Tabel 1. Data Trainig

\begin{tabular}{ccccccc}
\hline Nama & Usia & Gaji & $\begin{array}{c}\text { Penghasilan } \\
\text { Sampingan }\end{array}$ & Pinjama lain & Nominal Kredit & $\begin{array}{c}\text { Kelayakan } \\
\text { kredit }\end{array}$ \\
\hline Ardila & 23 & Rp 3.500.000 & Ada & Tidak Ada & RP 4.500.000 & Layak \\
Irman & 45 & Rp 2.800 .000 & Tidak Ada & Ada & Rp 2.000.000 & Tidak Layak \\
Nanda & 33 & Rp 2.500 .000 & Ada & Ada & Rp 850.000 & Layak \\
Aristika & 52 & Rp 5.700.000 & Ada & Tidak Ada & Rp 3.500.000 & Layak \\
Ermi & 40 & Rp 3.500.000 & Tidak Ada & Ada & Rp 850.000 & Layak \\
Dinda & 61 & Rp 4.200.000 & Tidak Ada & Ada & Rp 9.000.000 & Tidak Layak \\
Oppia & 50 & Rp 3.000.000 & Tidak Ada & Tidak Ada & Rp 9.000.000 & Tidak Layak \\
Irma & 18 & Rp 2.000.000 & Tidak Ada & Ada & Rp 500.000 & Layak \\
Dika & 20 & Rp 1.500.000 & Ada & Ada & Rp 4.500.000 & Tidak Layak \\
Ardian & 22 & Rp 2.200.000 & Ada & Ada & Rp 3.500.000 & Tidak Layak \\
Minarti & 24 & Rp 7.000.000 & Tidak Ada & Tidak Ada & Rp 500.000 & Layak \\
Selia & 40 & Rp 5.000.000 & Tidak Ada & Ada & Rp 1.500.000 & Layak \\
Vera & 30 & Rp 4.000.000 & Tidak Ada & Ada & Rp 750.000 & Layak \\
Indra & 55 & Rp 2.100.000 & Tidak Ada & Tidak Ada & Rp 7.500.000 & Layak \\
Akmal & 39 & Rp 1.800 .000 & Ada & Ada & Rp 2.500.000 & Tidak Layak \\
\hline
\end{tabular}

Tabel 2. Calon Pengaju Kredit Baru

\begin{tabular}{ccccccc}
\hline Nama & Usia & Gaji & $\begin{array}{c}\text { Penghasilan } \\
\text { Sampingan }\end{array}$ & Pinjama lain & Nominal Kredit & $\begin{array}{c}\text { Kelayakan } \\
\text { kredit }\end{array}$ \\
\hline Arya & 20 & Rp 3.500.000 & Tidak Ada & Ada & Rp 3.700.000 & $? ? ? ?$ \\
\hline
\end{tabular}

Keterangan kriteria pernyataan adalah sebagai berikut ini:

Tabel 3. Keterangan Pengasilan Sampingan

\begin{tabular}{ccc}
\hline No & Keteragan & Nilai \\
\hline 1 & Ya & 50 \\
2 & Tidak Ada & 10 \\
\hline
\end{tabular}


JURNAL MEDIA INFORMATIKA BUDIDARMA

Volume 5, Nomor 3, Juli 2021, Page 1063-1067

ISSN 2614-5278 (media cetak), ISSN 2548-8368 (media online)

Available Online at https://ejurnal.stmik-budidarma.ac.id/index.php/mib

DOI 10.30865/mib.v5i3.3100

Tabel 4. Keterangan Pinjaman Lain

\begin{tabular}{ccc}
\hline No & Keteragan & Nilai \\
\hline 1 & Ya & 10 \\
2 & Tidak Ada & 50 \\
\hline
\end{tabular}

Sehingga data yang didapatkan, sebagai berikut:

Tabel 5. Nilai Kriteria data Training

\begin{tabular}{|c|c|c|c|c|c|c|}
\hline Nama & Usia & Gaji & $\begin{array}{l}\text { Penghasilan } \\
\text { Sampingan }\end{array}$ & $\begin{array}{l}\text { Pinjama } \\
\text { lain }\end{array}$ & Nominal Kredit & $\begin{array}{c}\begin{array}{c}\text { Kelayakan } \\
\text { kredit }\end{array} \\
\end{array}$ \\
\hline Ardila & 23 & Rp 3.500.000 & 50 & 50 & RP 4.500.000 & Layak \\
\hline Irman & 45 & Rp 2.800.000 & 50 & 10 & Rp 2.000.000 & Tidak Layak \\
\hline Nanda & 33 & Rp 2.500 .000 & 50 & 10 & Rp $\quad 850.000$ & Layak \\
\hline Aristika & 52 & Rp 5.700 .000 & 50 & 50 & Rp 3.500 .000 & Layak \\
\hline Ermi & 40 & Rp 3.500 .000 & 10 & 10 & $\mathrm{Rp} \quad 850.000$ & Layak \\
\hline Dinda & 61 & Rp 4.200.000 & 10 & 10 & Rp 9.000.000 & Tidak Layak \\
\hline Oppia & 50 & Rp 3.000.000 & 10 & 50 & Rp 9.000.000 & Tidak Layak \\
\hline Irma & 18 & Rp 2.000 .000 & 10 & 10 & Rp $\quad 500.000$ & Layak \\
\hline Dika & 20 & Rp 1.500 .000 & 50 & 10 & $\operatorname{Rp} 4.500 .000$ & Tidak Layak \\
\hline Ardian & 22 & Rp 2.200 .000 & 50 & 10 & Rp 3.500 .000 & Tidak Layak \\
\hline Minarti & 24 & Rp 7.000.000 & 10 & 50 & Rp $\quad 500.000$ & Layak \\
\hline Selia & 40 & Rp 5.000 .000 & 10 & 10 & $\operatorname{Rp} 1.500 .000$ & Layak \\
\hline Vera & 30 & $\operatorname{Rp} 4.000 .000$ & 10 & 10 & Rp $\quad 750.000$ & Layak \\
\hline Indra & 55 & Rp 2.100.000 & 10 & 50 & Rp 7.500.000 & Tidak Layak \\
\hline Akmal & 39 & Rp 1.800 .000 & 50 & 10 & $\operatorname{Rp} 2.500 .000$ & Tidak \\
\hline
\end{tabular}

Sementara nilai dari calon pengaju kredit baru

Tabel 6. Nilai Calon Pengaju Kredit Baru

\begin{tabular}{ccccccc}
\hline Nama & Usia & Gaji & $\begin{array}{c}\text { Penghasilan } \\
\text { Sampingan }\end{array}$ & Pinjama lain & Nominal Kredit & $\begin{array}{c}\text { Kelayakan } \\
\text { kredit }\end{array}$ \\
\hline Arya & 20 & Rp 3.500.000 & 50 & 10 & $\operatorname{Rp~3.700.000~}$ & $? ? ? ?$ \\
\hline
\end{tabular}

\subsection{Penyelesaian}

Penyelesaian menggunakan metode K-Nearest Neighbor sebagai berikut ini:

$$
\begin{aligned}
& d\left(x_{1}, c\right) \\
& =\sqrt{(23-20)^{2}+(3.500 .000-3.500 .000)^{2}+(50-50)^{2}+(50-10)^{2}+(4.500 .000-3.700 .000)^{2}} \\
& \quad=8000 \\
& d\left(x_{2}, c\right) \\
& =\sqrt{(45-20)^{2}+(3.500 .000-3.500 .000)^{2}+(50-50)^{2}+(50-10)^{2}+(4.500 .000-3.700 .000)^{2}} \\
& \quad=1838478 \\
& d\left(x_{3}, c\right) \\
& =\sqrt{(33-20)^{2}+(3.500 .000-3.500 .000)^{2}+(50-50)^{2}+(50-10)^{2}+(4.500 .000-3.700 .000)^{2}} \\
& \quad d\left(x_{4}, c\right) \\
& =\sqrt{(52-20)^{2}+(3.500 .000-3.500 .000)^{2}+(50-50)^{2}+(50-10)^{2}+(4.500 .000-3.700 .000)^{2}} \\
& \quad=2209072 \\
& d\left(x_{5}, c\right) \\
& =\sqrt{(40-20)^{2}+(3.500 .000-3.500 .000)^{2}+(50-50)^{2}+(50-10)^{2}+(4.500 .000-3.700 .000)^{2}} \\
& \quad=2850000
\end{aligned}
$$

Lakukan hingga data terakhir yaitu ke-15 sesuai dengan jumlah data trainnig

$d\left(x_{15}, c\right)$

$$
\begin{aligned}
& =\sqrt{(20-20)^{2}+(1.800 .000-3.500 .000)^{2}+(50-50)^{2}+(10-10)^{2}+(2.500 .000-3.700 .000)^{2}} \\
& =2080865
\end{aligned}
$$

Dari keseluruhan hasil perhitungan terlihat beberapa nilai terdekat yang mirip dengan calon pengaju kredit baru yang bernama Arya medapatka hasil keputusan sebagai "Tidak Layak", sehingga pengaju tidak dapat diberikan izin untuk megambil kredit barang elektronik. 


\section{KESIMPULAN}

Perlunya dilakukan sebuah pengujian terhadap data pelaku kredit barang elektornik ini dapat membantu dalam hal menganalisa dan menghindari kemungkinan terjadi resiko antara pihak pengelola perusahaan dengan customers peminat barang dengan proses kredit, dengan menggunakan algoritma K-nearest neighbor yang memanfaatkan data-data terdahulu untuk mempermudah melihat pola data baru dalam mengambil keputusan, penggunaan metode K-nearest neighbour dapat digunakan untuk proses prediksi beberapa kasus lainnya, hasil dari pengguaan metode ini memiliki akurasi yang baik dan tepat sehingga mudah dipahami dikarenakan proses algoritma yang sangat sederhana.

\section{REFERENCES}

[1] V. Alfani, "Data Mining Untuk Klasifikasi Pinjaman Kredit Pensiunan Menggunakan Algoritma K-Nearest Neighbor," J. Pelita Inform., vol. 18, no. April, pp. 281-286, 2019.

[2] F. Nuraeni and U. Falah Purnama, "Sistem Pendukung Keputusan Pemberian Kredit Usaha Rakyat ( KUR ) Menggunakan Metode Weighted Product," Konf. Nas. Sist. Inform., vol. 5, no. 2, pp. 9-10, 2015.

[3] J. Han, M. Kamber, and J. Pei, Data Mining Concepts and Techniques. .

[4] M. N. Injadat, A. Moubayed, A. B. Nassif, and A. Shami, "Systematic ensemble model selection approach for educational data mining," Knowledge-Based Syst., vol. 200, p. 105992, Jul. 2020.

[5] Y. Zhang, G. Cao, B. Wang, and X. Li, “A novel ensemble method for k-nearest neighbor,” Pattern Recognit., vol. 85, pp. 13-25, 2019.

[6] M. R. Islam, A. R. M. Kamal, N. Sultana, R. Islam, M. A. Moni, and A. Ulhaq, "Detecting Depression Using KNearest Neighbors (KNN) Classification Technique," Int. Conf. Comput. Commun. Chem. Mater. Electron. Eng. IC4ME2 2018, no. February, pp. 1-4, 2018.

[7] A. Adiwijaya, M. N. Aulia, M. S. Mubarok, U. N. W, and F. Nhita, "A Comparative Study of MFCC-KNN and LPCKNN for Hijaiyyah Letters Pronounciation Classification System," in International Conference on Information and Communication Technology (ICoICT), 2017.

[8] Z. Geler, V. Kurbalija, M. Ivanović, and M. Radovanović, "Weighted kNN and constrained elastic distances for timeseries classification," Expert Syst. Appl., vol. 162, no. August, 2020.

[9] N. U. R. C. Aziz, P. S. Informatika, F. Komunikasi, D. A. N. Informatika, and U. M. Surakarta, "Implementasi algoritma knn untuk memprediksi potensi penyakit jantung dengan python flask," 2021.

[10] Ratino, N. Hafidz, S. Anggraeni, and W. Gata, "Sentimen Analisis Informasi Covid-19 menggunakan Support Vector Machine dan Naïve Bayes," J. JUPITER, vol. 12, no. 2, pp. 1-11, 2019.

[11] A. M. M. Anwar, P. Harsani, and A. Maesya, "Penentuan Daerah Prioritas Pelayanan Akta Kelahiran Dengan Metode K-Nn Dan K-Means,” Komputasi J. Ilm. Ilmu Komput. dan Mat., vol. 17, no. 1, pp. 319-328, 2020.

[12] K. Pemilikan et al., "Pendahuluan Latar Belakang Masalah Masalah yang akan diteliti berdasarkan latar belakang diatas adalah," 2007.

[13] Albi Anggito and Johan Setiawan, Metodologi Penelitian Kuantitatif. Jawa Barat: CV Jejak, 2018.

[14] H. Hasanah, "TEKNIK-TEKNIK OBSERVASI (Sebuah Alternatif Metode Pengumpulan Data Kualitatif Ilmu-ilmu Sosial)," At-Taqaddum, vol. 8, no. 1, p. 21, 2017.

[15] J. T. Informatika and U. Sriwijaya, "Prediksi Cuaca di Kota Palembang Berbasis," pp. 9-18.

[16] E. Buulolo, Data Mining Untuk Perguruan Tinggi. Deepublish, 2020.

[17] D. A. Anggoro and N. D. Kurnia, "Comparison of accuracy level of support vector machine (SVM) and K-nearest neighbors (KNN) algorithms in predicting heart disease,” Int. J. Emerg. Trends Eng. Res., vol. 8, no. 5, pp. 1689-1694, 2020 . 